\title{
Castration-Resistant Prostate Carcinoma Refractory to Second-Generation Androgen Receptor Axis-Targeted Agents
}

National Cancer Institute

\section{Source}

National Cancer Institute. Castration-Resistant Prostate Carcinoma Refractory to

Second-Generation Androgen Receptor Axis-Targeted Agents. NCI Thesaurus. Code C157497.

Castration-resistant prostate carcinoma which is refractory to second-generation androgen receptor axis-targeted agents, namely abiraterone and enzalutamide. 